\title{
Australian Journal of

\section{Comparison between the performance of genetically modified and conventional maize hybrids in Brazil}

\author{
Leandro Nogueira $\operatorname{Ramos}^{1}{ }^{*}$, Nara Oliveira Silva Souza ${ }^{2}$, Maurício Kobiraki ${ }^{1}$ \\ ${ }^{1}$ DuPont Pioneer, Cx. Postal 08283, CEP 73301-970, Planaltina, DF, Brazil \\ ${ }^{2}$ University of Brasília, FAV, Cx. Postal 04508, CEP 70910-900, Brasília, DF, Brazil
}

*Corresponding author: zleandro.ramos@gmail.com

\begin{abstract}
This study evaluates the yield performance of five maize hybrids (HP2251, HP5253, HP6490, HP8761 and HP0297). The aim of this work was to compare a non-transgenic (base genetics), a transgenic (Bt) with TC1507 and a transgenic (Bt) with MON810+TC1507 for each hybrid. The experiment was conducted in farms during 2014-2015 season, with natural infestation of fall armyworm and controlled by spraying insecticides. Three locations were planted in the Federal District, another two in Minas Gerais and three in Goiás (Brazil). The experimental design was a complete randomized block of $5 \times 3$ factorial arrangement in 8 locations, 5 hybrids and 3 versions, with two replicates. The plot size was four rows of five meters. For grain yield, data on weight was converted to kg.ha ${ }^{-1}$ and moisture was standardized to $14 \%$. Harvest data was submitted to statistical analysis using ASReml program to obtain yield predictions of genotypic effects. The estimation of variance components and genotypic parameters were obtained by Restrict Maximum Likelihood process. There were no significant differences when the treatments were analysed for the presence or absence of transgenic genes. The yield differences in the hybrids were due to the adaptability of those genotypes to the Brazil central high lands and not necessarily to the insertion of $B t$ genes. The transgenic insertions were not a determinant factor for yield reduction, indicating a specific interaction between genotypes and $B t$ events for yield. Therefore, a new transgenic hybrid always must be compared to its conventional counterpart before release decision.
\end{abstract}

Keywords: genetic resistance, Spodoptera frugiperda, transgenic versions, yield performance, Zea mays.

Abbreviations: BLUP_Best linear unbiased prediction; Bt_Bacillus thuringiensis; C_Conventinal; H_event TC1507; REML_Restricted maximum likelihood; $\mathrm{YH}_{-}$events MON 810 and TC1507.

\section{Introduction}

Brazil is the third maize (Zea mays L.) producing country, after the US and China, producing approximately 93 million tons. Brazilian maize exports account for $18 \%$ of total maize exports in the world, behind the US only. Maize production was estimated at a record 97.7 million tons in the 2016/2017 harvest, 46\% increase from 2016 to 2017 based on the expanded area and improved yields. Brazil's record maize output has led to record exports estimated at 35 million tons in 2016/2017, more than doubling the export volume of 2015 (USDA 2017). The summer maize area planted in the 2016/17 harvest was 5.4 million hectares, while the area of off-season crop (second harvest of 2015) was 12.1 million hectares. These areas place maize as the second largest crop in Brazil, behind soybeans only (Glycine $\max$ L.), with an estimate of more than 34 million hectares planted in 2016/17 (Conab 2017).

Maize has a broad scope in Brazil. In the southern and southeastern regions, maize is usually cultivated in the first season, while in the South and Midwest; it is grown in the off-season. However, maize is predominantly grown in tropical regions, where there is a high incidence of pests. The main maize pest is the fall armyworm, Spodoptera frugiperda (J. E. Smith) (Lepidoptera: Noctuidae). When not properly managed with chemical, biological and/or genetic controls, this pest causes variable losses depending on the phenological stage of the crop and period of the year. Several authors reported losses of up to $34 \%$ due to this factor (Cruz and Turpin, 1983, Cruz 1995, Figueiredo et al., 2006, Werle et al., 2011).

Some biological aspects of Spodoptera frugiperda favor the occurrence of severe infestations, which include high polyphagia, high reproductive capacity, ease of dispersion when adults and high number of cycles, which may reach eight per crop year. (Bernardi et al 2015). Those factors make crop difficult and considerably overload the control measures.

In addition to the aspects involved in pest biology, the area planted in the off season currently comprises approximately $59 \%$ of the total area of maize grown in Brazil. The other $41 \%$ are grown in the summer. Consequently, the maize planting window in Brazil is long, and maize is currently in different growth stages during the twelve months of the year (Conab 2017). This increases the pressure of pests in their adult stage; which, through migration, infests the maize fields in the early stages. 
Genetic breeding is widely used for different pests and crops in different parts of the world as a preventive, practical and effective option for insect control. In Brazil, the main genetic technique for the control of Spodoptera frugiperda is the hybrid of transgenic maize. It expresses the $B t$ gene, cloned from the bacterium Bacillus thuringiensis (Berliner), which encodes a protein toxic to several insects (Boulder 1993, Waquil et al., 2002).

In maize producing countries, 231 events were approved and 202 were approved specifically for the control of insects in maize. The Brazilian National Biosafety Committee (CTNBio) approved 39 commercial transgenic events related to maize in Brazil. Sixteen events were approved for resistance to lepidopteran insects, 6 for coleopterans and 3 for multiple insect resistances (ISAAA 2015). The MON810 event, YieldGard technology, was effective in controlling Spodoptera frugiperda and Helicoverpa zea in southern Georgia in maize hybrids in 1998 (Buntin et al., 2001).

Maize hybrids expressing the Cry1Ab protein (event MON810) or expressing the Cry1F protein (event TC1507), also tested in the USA, have been effective in the control of Spodoptera frugiperda and Helicoverpa zea in 2006 and 2007 (Buntin, 2008). Siebert et al., (2008) also obtained high control levels of Spodoptera frugiperda in transgenic maize hybrids expressing Cry1F in the southeast of the USA.

The Cry1F protein expressed in maize by the TC1507 event was released commercially in 2008 and marketed from 2009. It has been used successfully in Brazil for a few years. However, neonate larvae of Spodoptera frugiperda collected in TC1507 transgenic maize fields infesting the west of Bahia in 2011 were able to survive in Cry1F maize plants under laboratory conditions and subsequently produce fertile adults (Farias et al., 2014). This indicates that there is dynamism in the effectiveness of such transgenic events under crop conditions, planting dates and size of maize areas in Brazil. Therefore, other events expressing different Bt proteins are necessary for controlling Spodoptera frugiperda.

Studies on transgenic maize hybrids focus primarily on efficacy tests, both of insecticidal proteins and transgenic plants, and on the monitoring efficacy of a particular event over the years (harvests). However, it is important to compare how a similar performance of transgenic hybrid versions stands in relation to the corresponding versions of conventional hybrids. Unlike efficacy tests, performance tests should be performed on optimal planting, management, cultivation conditions and especially with insecticide applications in all treatments. Therefore, this study investigated the production yield of transgenic maize hybrids and their conventional counterparts conducted in grain production farms in 2014-2015 harvest to compare their productive potential.

\section{Results and Discussion}

\section{Grain yield performance}

Table 1 shows no differences on performance related to presence or absence of the Bt technology among the 15 types of maize hybrids ( 5 hybrids $\times 3$ versions - non GMO despite being conventional or containing the TC1507 $(\mathrm{H})$ or TC1507 + MON810 (YH) transgenic genes). The yield classification of hybrids shows no tendency to form groups because of such technology.

There was a significant difference in performance among the studied hybrids when considering the average productivity of the three versions of them. The HP2251 was the most productive $\left(11,421 \mathrm{~kg} \mathrm{ha}^{-1}\right)$ and the HP0291 was the least productive $\left(10,545 \mathrm{~kg} \mathrm{ha}^{-1}\right)$, representing $7.8 \%$ decreased productivity in relation to HP2251 (Table 2). Regardless of the aggregate technology, these data indicate a higher or lower productivity according to the adaptability of these genetic materials in the centre-west region of Brazil, and not necessarily the insertion of genes with a $B t$ technology.

\section{Grain yield performance between transgenic and non- transgenic hybrids}

There was $1.29 \%$ increase in productivity in the $\mathrm{YH}$ versions compared to conventional versions and $0.61 \%$ increase in the $\mathrm{H}$ version when considering the average productivity of the five hybrids together. Therefore, the insertion of genetic modified events $\mathrm{H}$ and $\mathrm{YH}$ did not affect the productivity of hybrids when they were analysed together (Figure 1).

Bortoloto and Silva (2009) found no differences between the hybrids 30F80Y and 30K75Y containing the $\mathrm{Y}$ technology and the conventional hybrids $30 \mathrm{~F} 80$ and $30 \mathrm{~K} 75$ regarding productivity and other agronomic traits.

Moraes et al., (2015) also found the conventional version and its isogenic of maize genotypes did not differ for grain yield.

In addition, Holland and Goodman (2003) evidenced that the use of the $B t$ technology did not result in increased productivity, with no differences between conventional and transgenic isogenic genotypes.

Table 3 shows the yield of the five hybrids in each version. For HP0297, the version HP0297YH achieved the highest productivity. However, the $\mathrm{HPO297H}$ version produced $4.14 \%$ less than the conventional version HP0297C. This also occurred to the hybrid HP5253, which produced $3.72 \%$ less than the conventional version HP5253C. On the other hand, HP5253YH produced $0.48 \%$ more than the conventional version HP5253C. Differences are irrelevant for HP2251. Both $\mathrm{H}$ and $\mathrm{YH}$ versions presented yield close to the conventional version.

When each hybrid is individually studied, there is discrepancy in productivity differences between versions (Table 3). This indicates a possible genotype/genes interaction of $B t$ proteins.

Regarding the hybrid HP6490, there was a considerable productivity increase in its transgenic versions compared to the conventional version HP6490C. The version $\mathrm{HP} 6490 \mathrm{H}$ achieved $17.1 \%$ higher production than the conventional version, and $\mathrm{HP} 6490 \mathrm{YH}$ reached a $14.5 \%$ higher production. It is important to consider that the $2.1 \%$ difference between the $\mathrm{H}$ and $\mathrm{YH}$ versions is not limiting for using the two sources of resistance to Spodoptera frugiperda in relation to yield. As for the hybrid HP8761, the two transgenic versions provided productions below the conventional version, with decreases of $4.5 \%(\mathrm{H})$ and $6.8 \%(\mathrm{YH})$, compromising the future inclusion of these versions in the market because they are not competitive with the conventional version in terms of yield (Table 3). 
Table1. Ranking of conventional maize hybrids $(\mathrm{C})$, transgenic version containing the TC1507 $(\mathrm{H})$ event and transgenic version containing the TC1507 + MON810 (YH) events in relation to grain yield achieved by $\mu$, Best linear unbiased prediction (BLUP) analyzed by the statistical software ASReml. Brasília-DF, 2015.

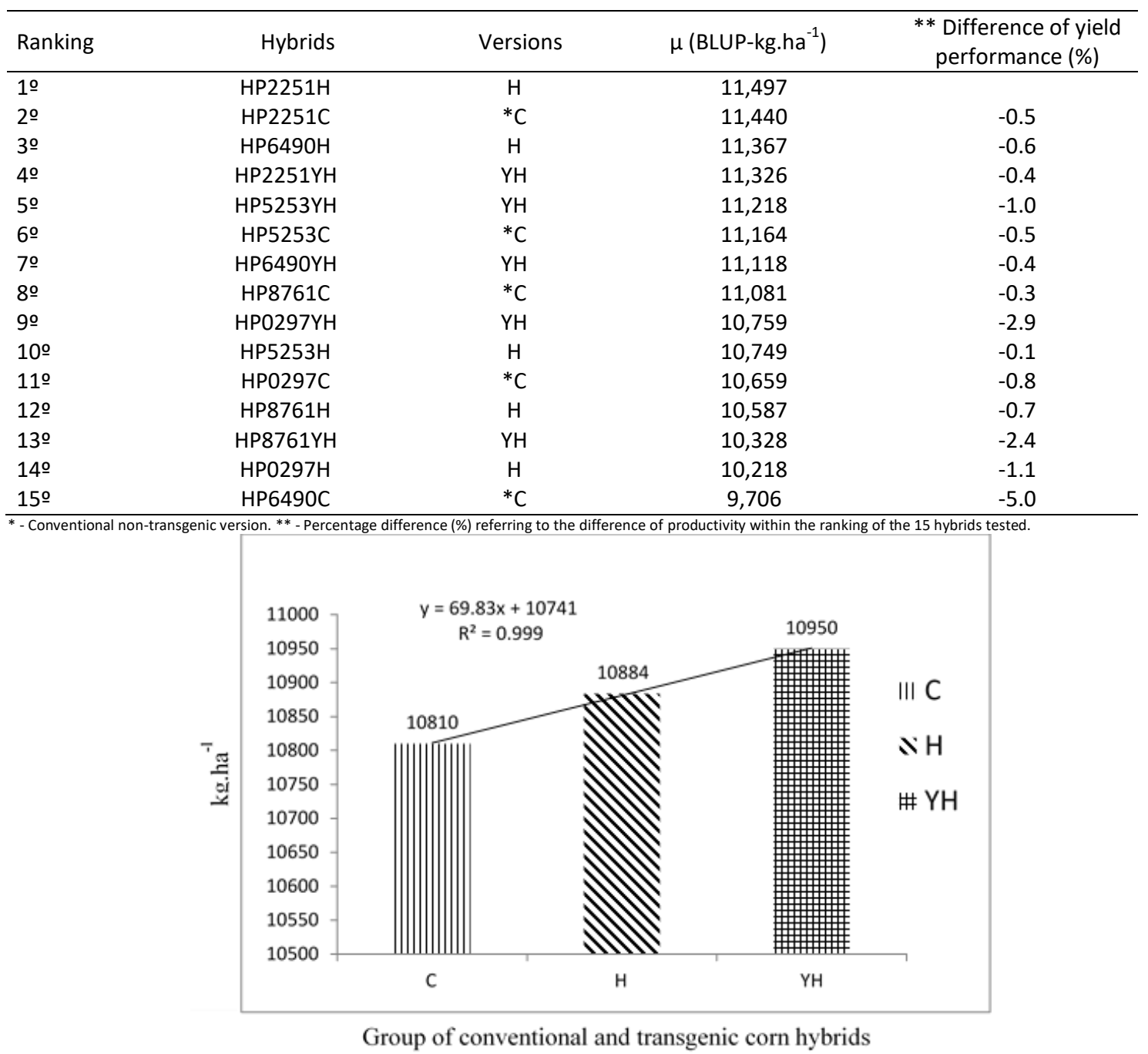

Fig 1. Means of conventional maize hybrids, transgenic version containing the TC1507 $(\mathrm{H})$ event and transgenic version containing the TC1507 + MON810 (YH) events in relation to grain yield achieved by Best linear unbiased prediction ( $\mu$-BLUP) analyzed by the statistical software ASReml. Brasília-DF, 2015.

Table 2. Classification of maize hybrids in relation to grain yield achieved by $\mu$ (BLUP) considering the conventional version, transgenic versions containing the TC1507 (H) event and transgenic version containing the TC1507 + MON810 (YH) events analyzed by the statistical software ASReml. Brasilia-DF, 2015.

\begin{tabular}{|c|c|c|c|}
\hline Ranking & Hybrid & $\mu^{*}$ (BLUP-kg.ha ${ }^{-1}$ ) & $\begin{array}{c}\text { ** Difference of yield performance } \\
(\%)\end{array}$ \\
\hline 10 & HP2251 & 11,421 & \\
\hline 20 & HP5253 & 11,044 & -3.3 \\
\hline 30 & HP6490 & 10,730 & -2.8 \\
\hline $4 \stackrel{0}{4}$ & HP8761 & 10,665 & -0.6 \\
\hline 5o & HP0297 & 10,545 & -1.1 \\
\hline
\end{tabular}

* - Average productivity of conventional, $\mathrm{H}$ and $\mathrm{YH}$ versions;

** Percentage difference (\%) referring to the difference of productivity within the ranking of the 5 groups of hybrids. 


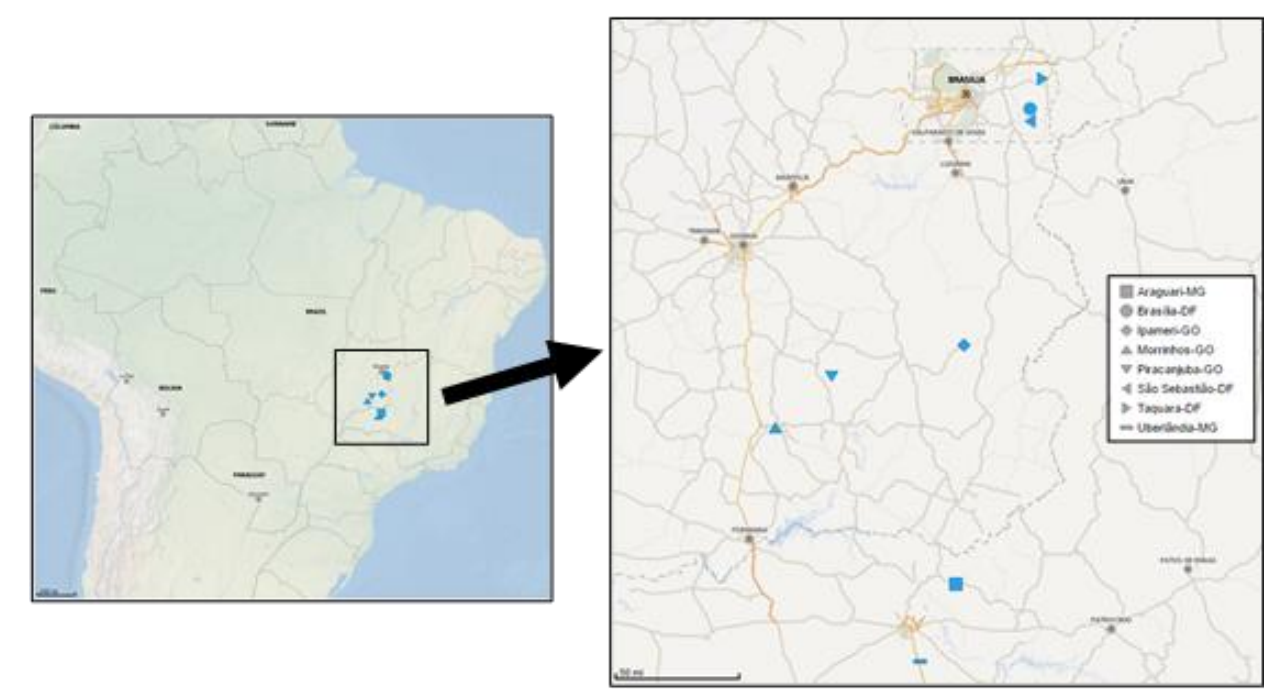

Fig 2. Eight farms in eight cities (Araguari, Brasília, Ipameri, Morrinhos, Piracanjuba, São Sebastião, Taquara e Uberlândia) The forms indicate where the experiments were conducted

Table 3. Percentage differences of yield of maize hybrids obtained by $\mu$ (BLUP) considering the conventional version, transgenic version containing the TC1507 (H) event and transgenic version containing the TC1507 + MON810 (YH) events analyzed by the statistical software ASReml. Brasília-DF, 2015.

\begin{tabular}{|c|c|c|c|c|}
\hline Hybrid & Transgenes & $\mu$ (BLUP-kg.ha $\left.{ }^{-1}\right)$ & $* \mathrm{H} \times \mathrm{C}$ & $* * \mathrm{YH} \times \mathrm{C}$ \\
\hline HP0297 & non-transgenic & 10,659 & & \\
\hline HP0297H & Cry1F & 10,218 & -4.1 & \\
\hline HР0297YH & Cry1F + Cry1Ab & 10,759 & & 0.9 \\
\hline HP5253 & non-transgenic & 11,440 & & \\
\hline HP5253H & Cry1F & 11,497 & -3.7 & \\
\hline HP5253YH & Cry1F + Cry1Ab & 11,326 & & 0.5 \\
\hline HP2251 & non-transgenic & 11,164 & & \\
\hline HP2251H & Cry1F & 10,749 & 0.5 & \\
\hline HP2251YH & Cry1F + Cry1Ab & 11,218 & & -1.0 \\
\hline HP6490 & non-transgenic & 9,706 & & \\
\hline HР6490H & Cry1F & 11,367 & 17.1 & \\
\hline HР6490YH & Cry1F + Cry1Ab & 11,118 & & 14.5 \\
\hline HP8761 & non-transgenic & 11,081 & & \\
\hline HP8761H & Cry1F & 10,587 & -4.4 & \\
\hline HP8761YH & Cry1F + Cry1Ab & 10,328 & & -6.8 \\
\hline
\end{tabular}

* - Percentage difference (\%) between the versions $\mathrm{H}$ and $\mathrm{C}$

** - Percentage difference (\%) between the versions $\mathrm{YH}$ and $\mathrm{C}$

Table 4. Geographical locations and altitude at sea level, dates of planting and harvest dates of the maize experiment. Brasília-DF, 2015.

\begin{tabular}{llllll}
\hline Locations & Latitude & Longitude & Altitude $(\mathrm{m})$ & Planting & Harvest \\
\hline Brasília-DF & -15.84961 & -47.49536 & 1,053 & $11 / 01 / 2014$ & $04 / 11 / 2015$ \\
São Sebastião-DF & -15.92563 & -47.49558 & 1,087 & $10 / 31 / 2014$ & $04 / 12 / 2015$ \\
Taquara-DF & -15.67230 & -47.42108 & 1,093 & $11 / 06 / 2014$ & $04 / 13 / 2015$ \\
Ipameri-GO & -17.25313 & -47.90713 & 1,172 & $11 / 11 / 2014$ & $04 / 14 / 2015$ \\
Morrinhos-GO & -17.73603 & -49.06414 & 758 & $11 / 09 / 2014$ & $04 / 15 / 2015$ \\
Piracanjuba-GO & -17.43679 & -48.721512 & 733 & $11 / 26 / 2014$ & $04 / 16 / 2015$ \\
Uberlândia-MG & -19.10682 & -48.174073 & 813 & $11 / 11 / 2014$ & $04 / 17 / 2015$ \\
Araguari-MG & -18.65594 & -47.955334 & 883 & $11 / 18 / 2014$ & $04 / 18 / 2015$ \\
\hline
\end{tabular}


Farinelli and Cerveira Júnior (2014) also detected grain yield increase of the hybrid AG8088 VTPRO, a transgenic with two $B t$ proteins resistant to Spodoptera frugiperda, when compared to the conventional AG 8088, which increased plant density per area. Lourenção \& Fernandes (2013) tested the effectiveness of the $B t$ hybrids Cry1Ab and Cry1F on Spodoptera frugiperda and their performance comparing with their conventional isolines, obtaining higher yields with transgenic versions in some cases.

\section{Materials and Methods}

\section{Plant materials}

Maize hybrids adapted to the central-north region of Brazil, with high productive potential and different maturity cycles were selected to determine the effect of the transgenic events insertion on grain yield. Another relevant factor was the good tolerance of these hybrids to the main foliar diseases, stalk rot and ear rot of maize, which is frequent in this region.

\section{Treatments}

Five maize hybrids were evaluated: HP2251, HP5253, HP6490, HP8761 and HP0297. Each hybrid had three different versions: conventional (C), expressing the protein Cry 1F (TC1507 event) (H), and another transgenic version expressing two Bt proteins, Cry $1 \mathrm{Ab}$ and Cry $1 \mathrm{~F}$ (MON810 and TC1507 events) (YH). The treatments were classified by grain yield where the first one was the most productive and the fifteenth was the least productive.

\section{Conduction of study}

The experiment was conducted in commercial fields during the agricultural year 2014-2015 at eight farms in three states of Brazil (Figure 2), three farms in the Federal District, two in Minas Gerais and other three in Goiás, as described in Table 4. These farms were chosen for their cerrado biome with altitudes above 700 meters. At all farms, plantations occurred directly over the remaining straws of previous crops. To ensure that the yield effect would not be influenced by productivity reduction, insecticides were applied to control the caterpillars that naturally infest the experiment. Three applications of insecticides were performed. Methomyl was applied to V2/V3 $\left(800 \mathrm{~mL}^{-h a^{-1}}\right)$; Spinosad was applied to V5/V6 (80 mL.ha $\left.{ }^{-1}\right)$; and Clorantraniliprole was applied to V10 $\left(110 \mathrm{~mL}^{-h a^{-1}}\right)$. These applications were made to control infestation by Spodoptera frugiperda larvae directed to conventional treatments.

\section{Experimental design}

The experimental design was randomized blocks with two replications, consisting of four rows of five meters per plot. Only the two central lines were considered useful plots. The row spacing was $0.75 \mathrm{~m}$. Planting was carried out mechanically with a vacuum planter set to sow 30 seeds every five meters. A double $5 \times 3$ factorial design was used: 5 hybrids and 3 versions. The experiment was planted in 8 farms. Plots were thinned when plants were at the V4 vegetative stage (four developed leaves). Twenty-three plants remained in each row, and a $0.7 \mathrm{~m}$-corridor distinguished plots following a same planting direction. The population throughout the test was kept stable after thinning with approximately 65.000 plants per hectare.

\section{Traits measured}

A grain yield evaluation was performed in the plot and estimated in kg.ha ${ }^{-1}$. The harvest was mechanically in a 6.45 $\mathrm{m}^{2}$ useful area using a specific harvester for four-line experiments. Production and grain humidity data at harvest were stored in on-board computer. Humidity was standardized at $14 \%$ to estimate the production per plot.

\section{Statistical analysis}

The Mixed Model methodology was used to obtain the Best Linear Unbiased Prediction (BLUP) of genotypic effects, and the process of Restricted Maximum Likelihood (REML) was used for the estimation of variance components and genotypic parameters. This method estimates values across distinct locations. Three commercial hybrids recommended for summer planting in the study areas hybrids, $30 \mathrm{~F} 53 \mathrm{H}$, $\mathrm{P} 3646 \mathrm{H}$ and $\mathrm{P} 3862 \mathrm{H}$, were used as control treatments. They showed different maturity stages. Controls were used for balancing data, being arranged diagonally in each test. Harvest data were extrapolated to kg.ha ${ }^{-1}$ and subjected to statistical analysis using the software ASReml. This method allows the evaluation of unbalanced experiment testing and may be used for both allogamous and autogamous plants with a mixed reproductive system (Garcia \& Nogueira 2005, Resende 2016).

\section{Conclusion}

Transgenic events TC1507 and TC1507 + MON810 were not the only determining factors for yield decrease; thus indicating specific interaction between genotypes and $B t$ events influencing the productivity of grain yield of maize. Therefore, it is essential to validate any new version to be released commercially for each maize hybrid regarding its productivity and its agronomic performance. It is extremely important to evaluate direct productivity components such as kernel rows, dimensions and weight of ear and grain. Indirect productivity components such as disease resistance and root volume can also reduce grain yield or even grains quality. The crucial point is to ensure that a new version of transgenic maize hybrid is equal to or better than its previous conventional or transgenic versions validated in terms of agronomic characteristics and yield.

\section{Acknowledgements}

The authors thank the University of Brasilia (FAV-UnB) for the support and DuPont Pioneer for providing the weather data and facilities to conduct this study.

\section{References}

Bernardi O, Bernardi D, Ribeiro SR, Okuma DM, Salmeron E, Fotoretto J, Medeiros FCL, Burd T, Omoto C (2015) Frequency of resistance to Vip3Aa20 toxin from Bacillus 
thuringiensis in Spodoptera frugiperda (Lepidoptera: Noctuidae) populations in Brazil. Crop Protec. 76:7-14.

Bortoloto V, Silva TRB (2009) Avaliação do desenvolvimento de milho convencional e milho Bt. Cult Saber. 2(3):89-95.

Boulder D (1993) Insect pest control by copying nature using genetically engineered crops. Phytochemistry. 34:14531466.

Buntin GD, Lee RD, Wilson DM, McPherson RM (2001) Evaluation of YieldGard transgenic resistance for control of fall armyworm and maize earworm (Lepidoptera: Noctuidade) on maize. Florida Entomol. 84(1):37-42.

Buntin GD (2008) Maize expressing CRY1AB or CRY1F endotoxin for fall armyworm and maize earworm (Lepidoptera: Noctuidade) management in field maize for grain production. Florida Entomol. 91(4): 523-530.

CONAB (2017) - Companhia Nacional de Abastecimento. Acompanhamento de Safras Brasileiras. 3 Levantamento de safra 2017/18 www.conab.gov.br/OlalaCMS/uploads/arquivos/18_01_11 _14_14_35_dezembro.pdf (Accessed December 29, 2017)

Cruz I, Turpin FT (1983), Yield impact of larval of the Fall armyworm (Lepidoptera: Noctuidade) to Midwhorl Growth Stage of Maize. J Econ Entomol. 76:1052-1054.

Cruz I (1995). A lagarta do cartucho do milho. Sete Lagoas: Embrapa Miho e Sorgo ( Embrapa Miho e Sorgo. Circular técnica, 21) $45 \mathrm{p}$.

Farias JR, Andow DA, Horikoshi RJ, Sorgatto JR, Fresia P, Santos AC (2014) Field-evolved to CRY1F maize by Spodoptera frugiperda (Lepidoptera: Noctuidade) in Brazil. Crop Protect. 64:150-158.

Farinelli R, Junior WRC (2014) Resposta de cultivares de milho transgênico e convencional a densidade populacionais. Rev Bras Milho Sorgo. 13(3): 336-346.

Figueiredo MLC, Dias AMPM, Criz I (2006) Relação entre a lagarta-do-cartucho e seus agentes de controle biológico natural na produção de milho. Pesq Agrop Bras. 41(12):1693-1698.
Garcia CH, Nogueira MCS (2005) Utilização de metodologia REML/BLUP na seleção de clones de eucalipto. Sci Forest. 68:107-112.

Holland JB, Goodman MM (2003). Combining ability of a tropical derived maize population with isogenic $B t$ and conventional testers. Maydica. 48:1-8.

ISAAA (2015) - International Service for the Acquisition of Agri-Biotech Applications. GM Crop Events approved in Brazil.

www.isaaa.org/gmapprovaldatabase/approvedeventsin/def ault.asp?CountryID=BR (Accessed December 14, 2015)

Lourenção ALF, Fernandes MG (2013) Avaliação do milho Bt Cry1Ab e Cry1F no controle de Spodoptera frugiperda (J.E.Smith, 1797) (Lepidoptera: Noctuidade) em condições de campo. Científica, 41(2):164-188.

Moraes ARA, Lourenção AL, Pateriniani MEAG (2015) Resistance of conventional and isogenic transgenic maize hybrids to Spodoptera frugiperda (Lepidoptera: Noctuidae). Bragantia, 74(1):50-57

Resende MDV (2016) Software Selegen - REML/BLUP: a useful tool for plant breeding.Crop Breed App Biotech, 16:330-339

Siebert MWKV, Tindall KV, Leonard BR, Duyn JWV, Babcock JM (2008) Evaluation of maize hybrids expressing Cry1F (Herculex (R) I insect protection) against fall armyworm (Lepidoptera: Noctuidae) in the southern United States. J Ent Sci. 43:41-51.

USDA (2017) - United States Department of Agriculture. Data \& Analysis: www.fas.usda.gov/regions/brazil (Accessed November 20, 2017)

Waquil JM, Villela FMF, Foster JE (2002) Resistência do milho (Zea mays L.) transgênico (Bt) à lagarta-do-cartucho, Spodoptera frugiperda (Smith) (Lepidoptera: Noctuidae). Rev Bras Milho Sorgo. 1(3):1-11.

Werle AJK, Nicolay RJ, Santos RF, Borsoi A, Secco D (2011) Evaluation of maize hybrids conventional and transgenic (Bt), with different insecticide application, on second-crop. Bras J App Tech Agric Sci. 4(1):149-166. 